\title{
NEGOTIATING ASYLUM
}


THE RAOUL WALLENBERG INSTITUTE HUMAN RIGHTS LIBRARY VOLUME 6 


\title{
Negotiating Asylum
}

The EU Acquis, Extraterritorial Protection and the Common Market of Deflection

\author{
by \\ Gregor Noll \\ LL M (Lund), \\ Researcher at the Faculty of Law, \\ University of Lund, Sweden
}

THE HAGUE / BOSTON / LONDON 
This is an open access title distributed under the terms of the CC BY-NC 4.0 license, which permits any non-commercial use, distribution, and reproduction in any medium, provided no alterations are made and the original author(s) and source are credited. Further information and the complete license text can be found at https://creativecommons.org/licenses/by-nc/4.0/

The terms of the cc license apply only to the original material. The use of material from other sources (indicated by a reference) such as diagrams, illustrations, photos and text samples may require further permission from the respective copyright holder.

ISBN 978-90-41-11431-o (hardback)

ISBN 978-90-04-46154-3 (e-book)

Copyright 2000 by Gregor Noll. Published by Koninklijke Brill Nv, Leiden, The Netherlands. Koninklijke Brill NV incorporates the imprints Brill, Brill Hes \& De Graaf, Brill Nijhoff, Brill Rodopi, Brill Sense, Hotei Publishing, mentis Verlag, Verlag Ferdinand Schöningh and Wilhelm Fink Verlag. Koninklijke Brill NV reserves the right to protect this publication against unauthorized use. 


\section{Acknowledgements}

THE PROCESS OF ITERATION and appropriation underlying this book would have been impossible without knowledgeable mediators. In the following, I should like to recall and acknowledge some of the guidance I have received underway.

I had the privilege to be supervised by a person playing a critical role in the dissemination of human rights within and beyond Sweden: Professor Göran Melander, Founding Director and Chairman of the Board of the Raoul Wallenberg Institute for Human Rights and Humanitarian Law. While Göran Melander has strongly influenced the domestic and international refugee discourse, he has taken care not to curtail this candidate's liberty in establishing and pursuing a project of his own. I am much indebted to him for letting me work in an environment of trust throughout the years. My thanks are also due to Professor Gudmundur Alfredsson, present Director of the Raoul Wallenberg Institute, who has willingly contributed a considerable dose of material comment, moral support and practical advice underway. Finally, I would like to thank both for their kind permission to publish this book in the Raoul Wallenberg Institute Series.

I owe a special debt of gratitude to Professor Jens Vedsted-Hansen, Aarhus University, who was my initiator into the discourse of refugee law and freely shared his insights, experience and research network with me. Taking international law seriously, Ulf Linderfalk, doctoral candidate at the Faculty of Law, acted as a thoughtful sparring partner in my attempts to make sense, and allowed me to draw on his profound knowledge of interpretation. Kristina Folkelius, Associate Desk Officer (Protection), 
UNHCR Geneva, has liberally screened my texts and ideas, providing insightful comments and counsel, and keeping me aware of critical developments in the field. Together, they formed an invaluable triangle of support in my confrontations with international refugee law.

Outside the realms of international law, but nonetheless close to the epicentre of reason, I have enjoyed a continuum of frank questions, sceptical observations and generous advice by my friends and colleagues Christian Dahlman, David Reidhav and Lotta Wendel. Their predatory relationship to the phenomenon formerly known as truth offered an exceptional stimulus during the daily shifts in the ivory tower.

Throughout the duration of this project, Professor Aleksander Peczenik has been prepared to comment on any of the unpolished bits and pieces which eventually formed this manuscript. His constant encouragement to look further and to dig deeper was an important source of inspiration, and responded to a need not easily satisfied in an institutional setting. On repeated occasions, Professor Peter Westberg simply acted as the right person in the right place, pulling the right levers and saying the right things. His notorious ability to administer constructive criticism in the right doses was of great importance to me, but probably more decisive was the continuum of personal support which he freely extended to my project.

I am much indebted to all the sagacious persons who contributed to the crafting of the present text by challenging its basic tenets, commenting on its vices as well as virtues, or opening new perspectives. Among them, Roland Bank, Rosemary Byrne, Anna Christensen, Fredrik Danelius, Åsa Gustafsson, Peo Hansen, Martin Isenbecker, Johannes van der Klaauw, Peter van Krieken, Joakim Nergelius, Karol Novak, Carl Söderbergh, Pauline Stoltz, Jerzy Sztucki, and Michael Williams warrant a specific mention for making a difference. Also, my warm thanks are due to friends and colleagues at the Faculty of Law and the Raoul Wallenberg Institute, who, for many years, have provided a favourable environment to this exercise. Last, but not least, my gratitude goes to my students, who more often than not delivered a strong impetus to think over the basics of our art.

Any research project is, of course, contingent on a material dimension. The basic funding was afforded by the Faculty of Law, which also made travel grants available throughout the years. The Institutet for rättsvetenskaplig forskning provided essential support in the last stages of 
the project. Finally, the Raoul Wallenberg Institute facilitated my participation in a number of conferences. I would like to extend my thanks to all three actors for their generosity.

The dedicated professionalism of Michaela Fahlbusch, librarian at the Max Planck Institute for International Law, Heidelberg, was crucial for exploring the riches on the shelves of the Institute. In Lund, both Habteab Tesfay, librarian at the Raoul Wallenberg Institute, and Olle Serin, librarian at the Faculty of Law, have gone out of their way to offer inestimable short-cuts to important books and articles. I would like to express my gratitude to all three.

With great vigilance and sensitivity, Robin Clapp edited the language of the manuscript, while Sara Thörnblad brought her impressive typographical talent to bear on the layout of text, tables and graphs, and ensured the overall consistency of the manuscript and its references. I would like to extend my thanks to both. It goes without saying that the responsibility for any errors in this book is neither theirs, nor that of other facilitators, named or unnamed, but mine alone.

There are reasons of the mind, and there are reasons of the heart. Birgitta Albertsson, Hildegard Noll and Björn-Ulf Noll have provided a subtle form of support which all too easily escapes the language of gratitude. Hence, I would like to dedicate this book to them.

Helsingborg, June 2000 
Gregor Noll - 9789004461543 Downloaded from Brill.com๑4/26/2023 07:03:26AM via free access 


\section{structure}

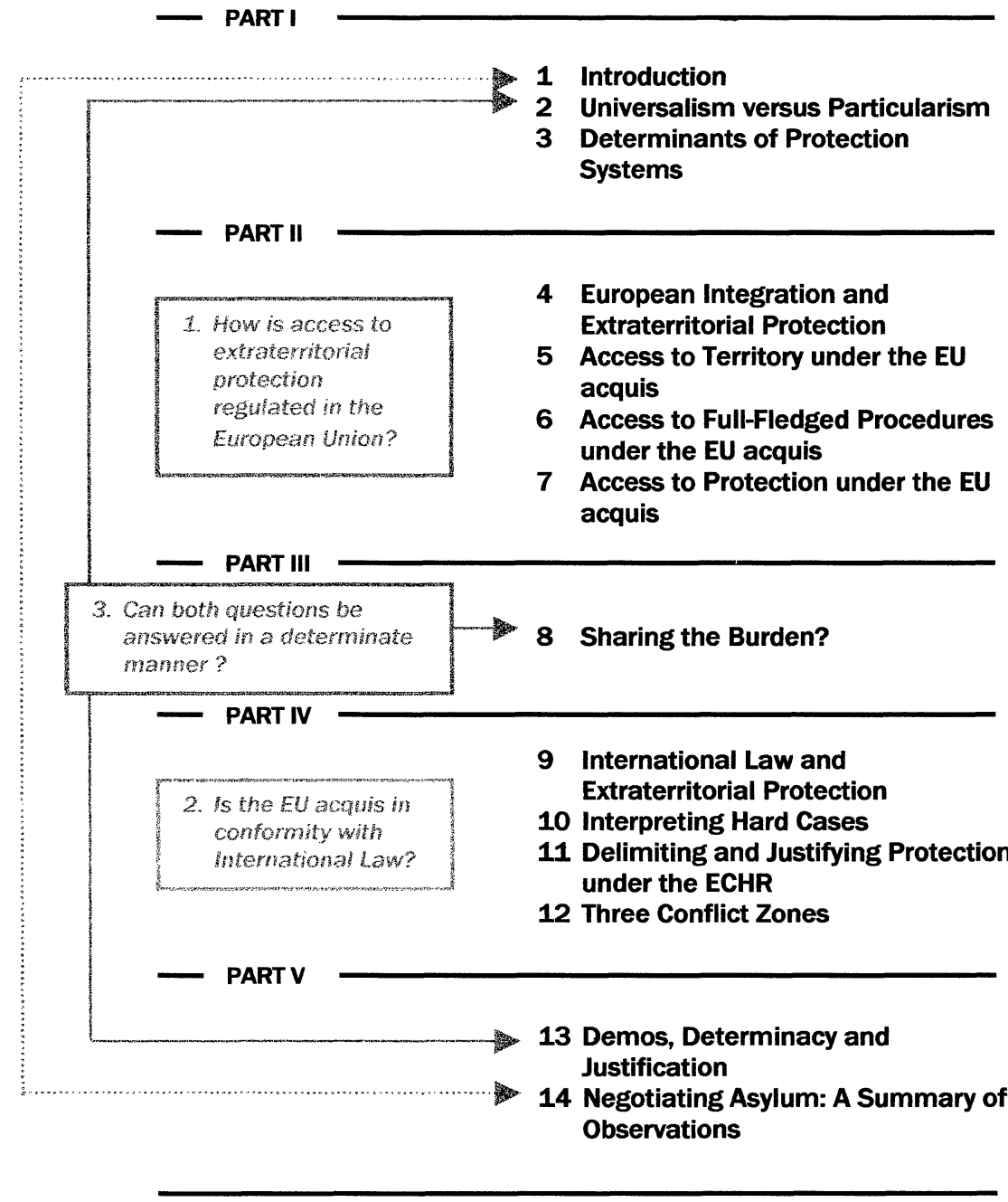


Gregor Noll - 9789004461543 Downloaded from Brill. com॰4/26/2023 07:03:26AM via free access 


\section{Table of Contents}

ACKNOWLEDGEMENTS V

STRUCTURE IX

$\begin{array}{ll}\text { TABLE OF CONTENTS XI } & \text { X }\end{array}$

LIST OF TABLES AND FIGURES XIX

ABBREVIATIONS XXI

1 INTRODUCTION 1

1.1 Reminiscences from a Continuing Past 1

1.1.1 Protecting Communities I 1

1.1.2 Protecting Communities II 3

1.1.3 Protecting Communities III 4

1.1.4 The Ambiguity of Hindsight 6

1.2 Identifying the Problem 11

1.3 Delimiting the Problem 12

1.3.1 'Access' 12

1.3.2 'Extraterritorial Protection' 15

1.3.3 'Regulated' 18

1.3.4 'In the European Union' 21

1.4 Identifying Law 23

1.4.1 International Law 26

1.4.1.1 The Concept of 'International Law' 26

1.4.1.2 Sources of International Law 28

1.4.1.3 Normative Hierarchies within International Law 32

xi 
TABLE OF CONTENTS

1.4.1.4 International Law and Justiciability Advantages 33

1.4.2 The Law of the European Union 36

1.4.2.1 Terminology 36

1.4.2.2 Primary and Secondary Law of the European Union 37

1.4.2.3 EC Law and Union Law: Conceptual Questions 38

1.4.2.4 EC Law: Sources and Normative Hierarchies 41

1.4.2.5 EC Law and Justiciability Advantages 46

1.4.2.6 Union law: Sources, Normative Hierarchies

1.4.2.7 A Normative Hierarchy between EC Law, Union

1.4.3 Intermediary Conclusion 55

1.5 Determining Law-Methodological Considerations 57

1.5.1 A Triple Dilemma $\quad 58$

1.5.2 Structuring Conflicts 61

1.5.3 The Legal-technical Level 63

1.5.4 The Qualitative Level 64

1.5.5 The Metalegal Level 65

$\begin{array}{lll}1.6 & \text { The Structure of Inquiry } & 67\end{array}$

2 UNIVERSALISM VERSUS PARTICULARISM 73

2.1 Choosing between Torture and Terrorism:

Mr. Chahal vs. the U.K. Population 73

$\begin{array}{ll}2.2 \text { Universalism } & 75\end{array}$

$\begin{array}{lll}2.3 & \text { Particularism } & 79\end{array}$

2.4 Human Rights versus Sovereignty 82

2.5 Artefact versus Organism 84

2.6 Meandering Arguments 89

3 DETERMINANTS OF PROTECTION SYSTEMS 97

3.1 The State Perspective 101

3.2 The Perspective of the Protection Seeker 107

$\begin{array}{ll}\text { 3.2.1 Access to Territory } & 108\end{array}$

3.2.2 Access to Full-fledged Procedures 112

3.2.3 Access to Protection 113

$\begin{array}{lll}3.3 & \text { Two Loops } & 114\end{array}$ 


\section{EUROPEAN INTEGRATION AND EXTRATERRITORIAL} PROTECTION

4.1 The Real World: Flight Movements to and within Europe since 1985

4.2 The Institutional World: From Schengen to Amsterdam 121

4.2.1 Freedom through Control: The 1985 White

Paper and the Single European Act 122

4.2.2 L'Europe accélérée: Schengen 123

4.2.3 Trying to Catch Up: The European Political Cooperation

4.2.3.1 The Dublin Convention 127

4.2.3.2 The Draft External Border Convention 128

4.2.3.3 Enter Soft Law: The London Resolutions 129

4.2.3.4 Swapping Information: CIREA and CIREFI 130

4.2.4 Maastricht-Progress through Split

Competencies? 132

4.2.5 Planning the Economy of Harmonization:
Amsterdam

4.2.5.1 Competencies and Obligations 136

4.2.5.2 Decision Making under Title IV 140

$\begin{array}{lll}4.2 .5 .3 & \text { The Role of the ECJ } & 142\end{array}$

4.2.5.4 The Position of Denmark, Ireland and the U.K. 145

4.2.6 The Integration of the Schengen acquis 146

4.2.7 The Variable Geometry of Integration 148

4.2.8 Enlarging the Union 153

$\begin{array}{ll}4.3 \text { Conclusion } & 156\end{array}$

\section{ACCESS TO TERRITORY UNDER THE EU ACQUIS 161}

5.1 Pre-entry Measures 161

5.1.1 The Harmonisation of Visa Regimes 162

5.1.1.1 Visa Harmonisation in the EU 164

5.1.1.2 Visa Harmonisation in the Schengen Group 169

$\begin{array}{ll}\text { 5.1.1.3 Mainstreaming the Schengen Visa acquis: } & 174 \\ \text { The Commission Proposal }\end{array}$

5.1.2 Measures Complementing Visa Regimes 175

$\begin{array}{lll}\text { 5.1.2.1 Carrier Sanctions } & 176\end{array}$

5.1.2.2 Sanctions against Human Smugglers 178

5.1.2.3 Pre-frontier Assistance and Training 179

$\begin{array}{lll}5.1 .3 & \text { Conclusion } & 181\end{array}$ 
5.2 Post-entry Measures: The Concept of Safe Third Countries

5.2.1 Allocation to other Member States 185

5.2.1.1 The Dublin Convention 185

5.2.1.2 Complementing Dublin: The Eurodac Proposal 198

5.2.2 Allocation to Non-Member States 199

5.2.2.1 The 1992 Resolution on Host Third Countries 199

$\begin{array}{ll}\text { 5.2.2.2 Complementing Allocation to Non-Member } & \\ & \text { States: Readmission Agreements }\end{array}$

5.2.2.2.1 The EU acquis on Readmission 205

5.2.2.2.2 Competencies after Amsterdam 206

$\begin{array}{lll}5.2 .3 \text { Conclusion } & 209\end{array}$

6 ACCESS TO FULL-FLEDGED PROCEDURES UNDER THE EU ACQUIS

6.1 The EU acquis Related to Procedure 215

6.2 The Spanish Protocol 224

6.3 Competencies after Amsterdam 227

6.4 Conclusion 232

7 ACCESS TO PROTECTION UNDER THE EU ACQUIS 233

7.1 Protection Categories 233

7.1.1 The EU Acquis Related to Protection Categories:

Questions of Scope

237

7.1.2 The Substantial Content of the Refugee Joint

Position 239

7.1.3 Competencies after Amsterdam 242

$\begin{array}{lll}7.1 .4 & \text { Conclusion } & 244\end{array}$

7.2 Return 244

7.2.1 The EU acquis Related to Return 247

7.2.2 The Schengen acquis Related to Return 253

7.2.3 Competencies after Amsterdam 254

7.2.4 Assessment of the EU acquis Related to Return 254

7.3 Intermediary Conclusion: Access to Protection in the EU 259 
8.1 The Concept and Function of Burden-sharing 263

8.1.1 The Objective of Burden-sharing 265

8.1.2 The Scope of Burden-sharing 267

8.1.2.1 Sharing Norms 270

8.1.2.2 Sharing Money 272

8.1.2.3 Sharing People 273

8.1.3 Assessing Burden-sharing Schemes 275

8.2 Burden-sharing and International Law 277

8.3 Burden-sharing and the EU acquis 285

8.3.1 Negotiations Preceding the 1995 Resolution 289

8.3.2 Comparison of the German Draft and the 1995 Resolution 293

8.3.3 The Impact of the Treaty of Amsterdam 297

8.3.4 The Solidarity Drafts: Merging Admission and Burden-sharing? 301

8.3.5 The Experimental Instruments of 1997 to $1999 \quad 309$

8.3.6 The Proposal on a European Refugee Fund 312

8.4 Concentrating the Burden 316

8.4.1 Concentration Effects of the Dublin Convention 317

8.4.2 Concentration Effects of Safe Third CountryArrangements 325

8.5 Two Interpretive Approaches 329

8.5.1 Subsidiarity 330

8.5.2 Game Theory 337

8.6 Conclusion 347

9 INTERNATIONAL LAW AND EXTRATERRITORIAL PROTECTION 353

9.1 Protection 357

9.1.1 A Right to Seek and Enjoy Asylum? 357

9.1.2 Express Prohibitions of Refoulement in Human
Rights Law

9.1.2.1 The 1951 Refugee Convention 362

9.1.2.2 The 1984 CAT 364

9.1.2.3 Other Express Prohibitions of Refoulement in
Human Rights Law? 
TABLE OF CONTENTS

9.1.3 Express Prohibitions of Refoulement in

Humanitarian Law 366

9.1.4 Implicit Prohibitions of Refoulement in Treaty Law 369

9.1.4.1 Human Rights Law 369

9.1.4.2 Humanitarian Law 372

9.2 Access to Territory 377

9.2.1 The ICCPR 377

9.2.2 The Fourth Protocol to the ECHR 378

9.3 Methodology of Interpretation 379

9.4 Identifying Hard Cases 382

9.4.1 Protection: Implicit Prohibitions of Refoulement 382

9.4.1.1 Article 3 ECHR and Article 7 ICCPR 383

9.4.1.2 Article 32 FC 384

9.4.2 Access to Territory 386

9.4.2.1 The Right to Leave and the Right to Entry 386

9.4.2.2 Explicit Prohibitions of Refoulement 387

9.4.2.3 Implicit Right to Access 389

9.4.3 Interim Conclusion on the First Stage 390

10 INTERPRETING HARD CASES 393

10.1 Protection: Implicit Prohibitions of Refoulement 394

$\begin{array}{lll}\text { 10.1.1 Article 3 ECHR } & 394\end{array}$

10.1.1.1 The Reasoning of the European Organs 394

10.1.1.2 Two Critics of the European Organs 400

10.1.1.3 Methodological Appraisal $\quad 404$

10.1.1.4 Reinterpreting Article 3 ECHR 407

10.1.2 Article 7 ICCPR $\quad 415$

10.2 Access to Territory 416

10.2.1 The Right to Leave and the Right to Entry 416

$\begin{array}{ll}\text { 10.2.1.1 A Universalist Reading } & 417\end{array}$

10.2.1.2 A Particularist Reading $\quad 420$

10.2.1.2.1 Complementing the Second Stage 420

10.2.1.2.2 The Third Stage 421

10.2.1.3 Conclusion $\quad 422$

10.2.2 Explicit Prohibitions of Refoulement 423

10.2.2.1 Article $33 \mathrm{GC} \quad 423$

10.2.2.1.1 The Second and Third Stage in the Light
of Doctrinal Debate

10.2.2.1.2 Article 33 GC in the Light of the Dublin Convention 431 
10.2.2.1.3 Conclusion 432

10.2.2.2 Article 3 CAT 432

10.2.2.2.1 The Second Stage 432

10.2.2.2.2 The Third Stage 435

10.2.2.3 Article 45 FC 438

10.2.3 Implicit Prohibitions of Refoulement 440

10.2.3.1 Article 7 ICCPR 440

10.2.3.2 Article 3 ECHR 441

10.3 Interim Conclusion on Hard Cases 444

10.4 Substance by Method? 446

10.4.1 What Does the Vienna Convention Do To the Law? 446

10.4.2 What Do Lawyers Do With the Vienna Convention? 448

10.4.3 Three Wildcards: Presumptions, Telos

and Indeterminacy 449

11 DELIMITING AND JUSTIFYING PROTECTION UNDER THE ECHR

453

11.1 The Case Law of the European Organs 454

11.2 A Hierarchy among Rights? 458

11.3 Irreparability as a Water-Shed? 464

11.4 A Hierarchy within Rights: The Concept of Positive Obligations $\quad 467$

11.5 Conclusion 473

12 THREE CONFLICT ZONES 475

12.1 Access to Territory: Visa Requirements and the ECHR 476

12.1.1 Determinants of Discrimination Arguments 480

12.1.2 Discrimination under the ECHR? 482

12.1.3 Refining Proportionality Reasoning 485

12.1.4 Applying the Refined Proportionality Test to Visa

12.1.5 Appraisal 493

12.2 Access to Territory and Protection: Choosing between Dublin and Geneva? 494

12.2.1 Permissive Tolerance, Margin of Discretion or Unitary Interpretation?

496

12.2.2 Delimiting Protection Categories: Persecution by Third Parties 
TABLE OF CONTENTS

12.2.2.1 The 1951 Refugee Convention 512

$\begin{array}{lll}\text { 12.2.2.2 The CAT } & 521\end{array}$

12.2.2.3 The ECHR 524

12.2.3 Appraisal 535

12.3 Access to Full-Fledged Procedures: The Spanish

Protocol and Discrimination 536

12.3.1 Interpreting the Spanish Protocol in the Light of
International Law

12.3.2 Discrimination under the 1951 Refugee

12.3.3 Discrimination under the ICCPR and ECHR? 546

12.3.4 Discrimination under the TEC? 549

12.3.5 Appraisal 552

12.4 Conclusion $\quad 556$

13 DEMOS, DETERMINACY AND JUSTIFICATION 559

13.1 Tilting the Balance: Constructions of the Demos 562

13.1.1 The European Union and the Demos Dilemma 564

13.1.2 Essence: Distinguishing Friend and Foe 568

13.1.3 Contract: Universality by Consent 575

13.1.4 Indeterminacy: The Particularist's Last Trump? 581

13.2 The Anomaly of Transnational Human Rights 586

13.3 Strasbourg and the Exceptional: Legitimation in the Courtroom?

14 NEGOTIATING ASYLUM: A SUMMARY OF OBSERVATIONS 593

$\begin{array}{ll}\text { CASES } & 599\end{array}$

INTERNATIONAL TREATIES 603

INSTRUMENTS AND DOCUMENTS RELATED TO THE EU ACQUIS $\quad 605$

$\begin{array}{ll}\text { LITERATURE } & 615\end{array}$

$\begin{array}{ll}\text { INDEX } & 639\end{array}$ 


\section{List of Tables and Figures}

Figure 1: $\quad$ The Structure of Inquiry. 69

Figure 2: $\quad$ Three determinants affecting the costs 104 of protection regimes.

Table 1: The variable geometry of integration under Title IV TEC and within the Schengen co-operation.

Table 2: $\quad$ UNHCR/IOM Humanitarian evacuations of Kosovar refugees from the FYR of Macedonia from 5 April through 25 June 1999.

Table 3: $\quad$ Distribution of cases under the Dublin Convention between Germany and other Member States, 1 July-30 September 1998.

Table 4: $\quad$ Net Senders and Net Receivers under the Dublin Convention in the First and Third Quarter of 1998.

Table 5: $\quad$ Outcomes of Asylum Applications in Three Candidate Countries in 1998.

Table 6: $\quad$ Applicability ratione loci of Selected Norms in Relation to a Potentional Host State. Results of the First Stage.

Table 7: $\quad$ Applicability ratione loci of Selected Norms in Relation to a Potentional Host State. Results of the First, Second and Third Stage. 


\section{LIST OF TABLES AND FIGURES}

Table 8: $\quad$ Asylum claims filed in Germany by nationals of other Member States (1998).

Table 9: $\quad$ Prohibition of Discrimination on grounds of nationality 556 and justiciability. Comparison of four international treaties. 


\section{Abbreviations}

\begin{tabular}{|c|c|}
\hline AAB & Alien Appeals Board \\
\hline AIL & American Journal of International Law \\
\hline ATV & Airport Transit Visa \\
\hline BGBI & Bundesgesetzblatt \\
\hline $\mathrm{BiH}$ & Republic of Bosnia and Herzegovina \\
\hline BMI & Bundesministerium des Innern \\
\hline BVerwG & Bundesverwaltungsgericht \\
\hline BVerwGE & $\begin{array}{l}\text { Entscheidungssammlung des } \\
\text { Bundesverwaltungsgerichts }\end{array}$ \\
\hline BYIL & British Yearbook of International Law \\
\hline CAHAR & $\begin{array}{l}\text { Ad Hoc Committee of Experts on the Legal Aspects } \\
\text { of Territorial Asylum, Refugees and Stateless } \\
\text { Persons }\end{array}$ \\
\hline CAT & Convention against Torture \\
\hline $\mathrm{CCl}$ & Common Consular Instruction \\
\hline CERD & $\begin{array}{l}\text { International Convention on the Elimination of All } \\
\text { Forms of Racial Discrimination }\end{array}$ \\
\hline CMLR & Common Market Law Review \\
\hline CFSP & Common Foreign and Security Policy \\
\hline DC & Dublin Convention \\
\hline DRC & Danish Refugee Council \\
\hline ECR & European Court Reports \\
\hline EEA & European Economic Area \\
\hline
\end{tabular}




\begin{tabular}{|c|c|}
\hline ECHR & $\begin{array}{l}\text { Convention for the Protection of Human Rights and } \\
\text { Fundamental Freedoms }\end{array}$ \\
\hline EC & European Community \\
\hline ECJ & European Court of Justice \\
\hline ECRE & European Council on Refugees and Exiles \\
\hline ECtHR & European Court of Human Rights \\
\hline EJIL & European Journal of International Law \\
\hline EPC & European Political Cooperation \\
\hline EU & European Union \\
\hline EZAR & $\begin{array}{l}\text { Entscheidungssammlung zum Ausländer- und } \\
\text { Asylrecht (Germany) }\end{array}$ \\
\hline FC & Fourth Convention \\
\hline GC & Convention on the Status of Refugees \\
\hline GYIL & German Yearbook of International Law \\
\hline HEP & Humanitarian Evacuation Programme \\
\hline HLWG & High Level Working Group on Asylum and Migration \\
\hline ICCPR & International Covenant on Civil and Political Rights \\
\hline ICESCR & $\begin{array}{l}\text { International Covenant on Economic, Social and } \\
\text { Cultural Rights }\end{array}$ \\
\hline ICJ & International Court of Justice \\
\hline ICMPD & $\begin{array}{l}\text { International Centre for Migration Policy } \\
\text { Development }\end{array}$ \\
\hline ICRC & International Committee of the Red Cross \\
\hline IGC & Inter-governmental Conference \\
\hline IGCARMP & $\begin{array}{l}\text { Inter-Governmental Consultations on Asylum, } \\
\text { Refugee and Migration Policies in Europe, North } \\
\text { America and Australia }\end{array}$ \\
\hline IHL & International Humanitarian Law \\
\hline IJRL & International Journal of Refugee Law \\
\hline ILC & International Law Commission \\
\hline ILPA & Immigration Law Practitioners' Association \\
\hline ILR & International Law Reports \\
\hline JHA & Justice and Home Affairs \\
\hline
\end{tabular}




\begin{tabular}{ll} 
LNTS & League of Nations Treaty Series \\
\hline MPG & Migration Policy Group \\
\hline MUA & Manifestly unfounded applications \\
\hline NATO & North Atlantic Treaty Organisation \\
\hline NGO & Non-governmental organisation \\
\hline NJIL & Nordic Journal of International Law \\
\hline OJ & Official Journal \\
\hline OSCE & $\begin{array}{l}\text { Organisation for Security and Co-operation in } \\
\text { Europe }\end{array}$ \\
\hline
\end{tabular}

Rev. trim. dr. h. Revue trimestrielle des droits de l'homme

\begin{tabular}{ll}
\hline RGBI & Reichs'gesetzblatt \\
\hline SC & Schengen Convention \\
\hline SCO & Safe countries of origin \\
\hline SIB & Statute of the International Court of Justice \\
\hline SIS & State Immigration Board \\
\hline STC & Schengen Information System \\
\hline TEC & Safe third countries \\
\hline TEC/Maastricht & $\begin{array}{l}\text { Treaty establishing the European Community as } \\
\text { amended by the Treaty of Amsterdam }\end{array}$ \\
\hline TEU & $\begin{array}{l}\text { Treaty on European Union as amended by the } \\
\text { Treaty of Amsterdam }\end{array}$ \\
\hline TEU/Maastricht & $\begin{array}{l}\text { Treaty on European Union as worded by the Treaty } \\
\text { of Maastricht }\end{array}$ \\
\hline UDHR & Universal Declaration of Human Rights \\
\hline UN & United Nations \\
\hline UN Doc. No. & United Nations Document Number \\
\hline UNC & Charter of the United Nations \\
\hline UNHCR & United Nations High Commissioner for Refugees \\
\hline UNCHR EXCOM & $\begin{array}{l}\text { Executive Committee Of The High Commissioner's } \\
\text { Programme }\end{array}$ \\
\hline UNTS & United Nations Treaty Series \\
\hline
\end{tabular}




\section{ABBREVIATIONS}

\begin{tabular}{ll} 
Vol. & Volume \\
\hline VTC & Vienna Convention on the Law of Treaties \\
\hline WGI & Working Group on Immigration \\
\hline YILC & Yearbook of the International Law Commission \\
\hline ZAR & Zeitschrift für Ausländerrecht und Ausländerpolitik
\end{tabular}

